\title{
NITROGEN MINERALIZATION AND PRODUCTIVITY IN 50 HARDWOOD AND CONIFER STANDS ON DIVERSE SOILS
}

\author{
Peter B. Reich, ${ }^{1}$ David F. Grigal, ${ }^{1}$ John D. Aber,${ }^{2}$ And Stith T. Gower ${ }^{3}$ \\ ${ }^{1}$ Department of Forest Resources, University of Minnesota, St. Paul, Minnesota 55108 USA \\ ${ }^{2}$ Complex Systems Research Center, University of New Hampshire, Durham, New Hampshire 03824 USA \\ ${ }^{3}$ Department of Forestry, University of Wisconsin, Madison, Wisconsin 53706 USA
}

\begin{abstract}
The generality of relationships between soil net nitrogen $(\mathrm{N})$ mineralization, aboveground $\mathrm{N}$ cycling, and aboveground net primary production (ANPP) for temperate forest ecosystems is unclear. It is also not known whether these variables and their relationships differ between evergreen and deciduous forests, or across soil types. To address these questions we compiled data on annual rates of in situ net $\mathrm{N}$ mineralization and ANPP for 16 conifer and 34 hardwood forests, including plantations and natural stands on a range of soils at six locations in Wisconsin and Minnesota, USA. For 31 natural stands, 48 stands with native species (including plantations), and all data, ANPP increased linearly with annual net $\mathrm{N}$ mineralization rates. Native evergreen conifer and two deciduous hardwood types (oaks and mesic hardwoods) followed similar patterns in this regression, indicating common functional relationships at the ecosystem level. The relationship of $\mathrm{N}$ mineralization and ANPP differed between finer textured Alfisol soils and sandier Entisols, with higher ANPP at any given $\mathrm{N}$ mineralization level in Alfisols. A multiple regression of $\mathrm{N}$ mineralization on soil texture (percentage silt plus clay), litterfall $\mathrm{N}$, and mean annual temperature explained $81 \%$ of the variance in annual $\mathrm{N}$ mineralization for natural stands, and a multiple regression of ANPP on soil texture and annual $\mathrm{N}$ mineralization rate explained $83 \%$ of the variance in ANPP.

Naturally regenerated forest types differed in mean annual net $\mathrm{N}$ mineralization, litterfall $\mathrm{N}$, and ANPP, and all were greater in oaks than in mesic hardwoods or conifers, respectively. However, differences among the 50 stands and six locations were largely a result of differences in soils and stand origin. For all natural hardwood stands, ANPP and N mineralization were greater on fine-textured Alfisols than on sandy Entisols. For evergreen conifers, ANPP and N mineralization were greater in plantations on Alfisols than in natural stands on Histosols, Entisols, or Spodosols. Hardwood and evergreen conifer stands did not differ significantly in ANPP or N mineralization on comparable soils and stand origin: they differed neither as plantations on Alfisols nor as natural stands on Entisols. This suggests that observed average differences among natural forest types in ANPP and N mineralization resulted largely from variation in their distribution on differing soils, and not from feedback effects on $\mathrm{N}$ mineralization or differing productivity per available $\mathrm{N}$.

These data suggest that, at a regional scale, at least half of the variation in ANPP can be attributed to variation in annual $\mathrm{N}$ mineralization. Both ANPP and N mineralization differ more strongly with soil type/parent material than with forest type; ANPP at any given level of $\mathrm{N}$ mineralization is higher on silty/loamy Alfisols than on sandy Entisols, Histosols, or Spodosols, but not different for coniferous and broad-leaved deciduous species. There is no indication of $\mathrm{N}$ saturation of ANPP within the range of natural $\mathrm{N}$ availability in these forests.
\end{abstract} forest.

Key words: deciduous; evergreen; mineralization; nitrogen; productivity; soil types; temperate

\section{INTRODUCTION}

Significant advances have been made in the past 15 yr toward understanding the relationships among nitrogen $(\mathrm{N})$ availability, $\mathrm{N}$ cycling, and net primary production in temperate forest ecosystems (e.g., Aber and Melillo 1982, Van Cleve et al. 1983, Pastor et al. 1984, Nadelhoffer et al. 1985, Zak et al. 1989, Binkley and Hart 1989, Aber et al. 1991, Gower and Son 1992).

Manuscript received 2 January 1996; revised 10 May 1996; accepted 15 May 1996.
However, substantial uncertainty exists and discrepancies between studies remain unresolved, such as those involving studies in the Great Lakes region of the United States. Many (but not all) site-specific studies show significant relationships between productivity and some soil-based measure of $\mathrm{N}$ availability (Pastor et al. 1984, Nadelhoffer et al. 1985, Zak et al. 1989, Gower and Son 1992). These relationships may not hold at large scales, though. Across a broad climatic gradient including grassland and forest ecosystems, no general relationship was found between potential net 
TABLE 1. Study area/location, soil order, and stand descriptions for the 50 forest stands used in this study. Climate data include mean annual temperature (Temp.) and total annual precipitation (Ppt.) from long-term averages. Soil orders: Alfisol (Alf.), Entisol (Ent.), Histosol (Hist.), Spodosol (Spod.), and Mollisol (Moll.).

\begin{tabular}{|c|c|c|c|c|c|c|c|c|}
\hline \multirow[b]{2}{*}{ Study area/location } & \multirow[b]{2}{*}{ Lat. N, Long. W } & \multirow[b]{2}{*}{ Soil orders } & \multicolumn{4}{|c|}{ Stand type and number } & \multicolumn{2}{|c|}{$\begin{array}{c}\text { Annual } \\
\text { climate data }\end{array}$} \\
\hline & & & Oak & $\begin{array}{l}\text { Mesic } \\
\text { hard- } \\
\text { wood }\end{array}$ & $\begin{array}{l}\text { Coni- } \\
\text { fer }\end{array}$ & Total & $\frac{\text { Temp. }}{\left({ }^{\circ} \mathrm{C}\right)}$ & $\begin{array}{l}\text { Ppt. } \\
\text { (mm) }\end{array}$ \\
\hline $\begin{array}{l}\text { University of Wisconsin } \\
\text { Arboretum, Madison, Wisconsin }\end{array}$ & $43^{\circ} 03^{\prime} \mathrm{N}, 89^{\circ} 25^{\prime} \mathrm{W}$ & Alf., Moll. & 4 & 9 & 4 & 17 & 8.0 & 820 \\
\hline Blackhawk Island, & $43^{\circ} 40^{\prime} \mathrm{N}, 89^{\circ} 45^{\prime} \mathrm{W}$ & Alf., Ent., Spod., Hist. & 3 & 2 & 3 & 8 & 7.6 & 800 \\
\hline Coulee Experimental Forest, & $43^{\circ} 52^{\prime} \mathrm{N}, 91^{\circ} 51^{\prime} \mathrm{W}$ & Alf. & 1 & 0 & 4 & 5 & 6.6 & 780 \\
\hline $\begin{array}{l}\text { Cedar Creek Natural History Area, } \\
\text { Bethel, Minnesota } \\
\text { North Highlands State Forest, }\end{array}$ & $45^{\circ} 25^{\prime} \mathrm{N}, 93^{\circ} 10^{\prime} \mathrm{W}$ & Ent., Hist. & 9 & 4 & 4 & 17 & 5.5 & 726 \\
\hline $\begin{array}{l}\text { Boulder Junction, Wisconsin } \\
\text { Cloguet Forestry Center. }\end{array}$ & $46^{\circ} 10^{\prime} \mathrm{N}, 89^{\circ} 40^{\prime} \mathrm{W}$ & Spod. & 0 & 0 & 1 & 1 & 4.6 & 790 \\
\hline Cloquet, Minnesota & $46^{\circ} 43^{\prime} \mathrm{N}, 92^{\circ} 28^{\prime} \mathrm{W}$ & Ent. & 0 & 2 & 0 & 2 & 4.0 & 760 \\
\hline
\end{tabular}

$\mathrm{N}$ mineralization and productivity (Zak et al. 1994). Therefore, investigating the relationships between $\mathrm{N}$ availability and ANPP at a regional scale is warranted.

Although net primary production is known to be broadly related to $\mathrm{N}$ availability, the strength, form, and generality of this relationship is poorly known, as is the predictability of differences in $\mathrm{N}$ cycling and productivity among diverse forest types, such as hardwoods and conifers. For instance, data from Pastor et al. (1984) and Lennon et al. (1985) suggested a curvilinear relationship between annual aboveground net primary production (ANPP) and $\mathrm{N}$ availability for forests in Wisconsin, with productivity increasing and then leveling off as $\mathrm{N}$ increased. This suggests a saturation of $\mathrm{N}$ response within the range of typical $\mathrm{N}$ availability. In contrast, in other studies in Wisconsin and Minnesota, Nadelhoffer et al. (1985) found a linear relation between ANPP and $\mathrm{N}$ availability, whereas Gower and colleagues (Gower and Son 1992, Gower et al. 1993) and Grigal and Homann (1994) found no relationship between ANPP and $\mathrm{N}$ availability for closed-canopy forests. Results of studies of stem (wood) productivity in relation to $\mathrm{N}$ availability in Great Lakes' States forests have been equally variable. Nadelhoffer et al. (1985) reported a linear increase in stem productivity, and Pastor et al. (1984) and Zak et al. (1989) a curvilinear increase, whereas Lennon et al. (1985), Gower and colleagues (Gower and Son 1992, Gower et al. 1993), and Grigal and Homann (1994) found no relationship between stem productivity and $\mathrm{N}$ availability.

Direct comparison of these studies is problematic, because the range of variation in productivity and in $\mathrm{N}$ cycling in each study emphasized different controls. Such differences include contrasts made across both forest types and strong topographic/edaphic gradients (Pastor et al. 1984, Grigal and Homann 1994) vs. contrasts across soils but within a forest type (Zak et al. 1989) vs. contrasts across species but on a common soil type (Gower and Son 1992, Gower et al. 1993). Moreover, different authors have used different indices of $\mathrm{N}$ availability, such as annual in situ net $\mathrm{N}$ mineralization rates, estimated annual $\mathrm{N}$ uptake, and/or potential $\mathrm{N}$ mineralization, compounding the difficulty of cross-location and cross-study comparisons. Finally, the relatively small sample size in each study (i.e., 510 stands), and the inherent variability and error associated with measurement of $\mathrm{N}$ mineralization (Binkley and Hart 1989) make it difficult to determine if a general relationship exists for all forests.

The uncertainties associated with these findings led us to ask the following questions with respect to regional variation among forest stands. (1) Are annual ANPP, net $\mathrm{N}$ mineralization, and litterfall $\mathrm{N}$ content significantly related? (2) Are ANPP and its components (wood and foliage production) better related to annual aboveground $\mathrm{N}$ cycling or to soil $\mathrm{N}$ mineralization? (3) Does ANPP, $\mathrm{N}$ mineralization, and/or $\mathrm{N}$ cycled in litterfall (and associated measures of ecosystem $\mathrm{N}$ use efficiency) differ among forest types or soil groups? (4) Is the relationship between ANPP and N availability different for different forest types or soils groups?

To address these issues we examine relationships between ANPP, N litterfall cycling, and soil $\mathrm{N}$ mineralization for 50 forest stands in Wisconsin and Minnesota, USA.

\section{Study Areas and Methods}

For this analysis we attempted to use as many comparable data as possible. We studied 50 forest stands (i.e., sites) at six study areas in Wisconsin and eastern Minnesota (Table 1). The study areas are all within a roughly comparable ecological zone, near the western edge of the eastern deciduous biome. The sites include a wide range of soil types, and at four of the six locations both deciduous hardwood and conifer-dominated stands were studied. Comparable methods were used at all sites to measure ANPP, aboveground litter- 
fall $\mathrm{N}$, and soil $\mathrm{N}$ mineralization rates. Many of these data have been previously reported in location-specific studies (Pastor et al. 1984, Lennon et al. 1985, Nadelhoffer et al. 1985), although in some cases the data were summarized by vegetation type rather than presented by individual stands (Grigal and Homann 1994) and/or reported separately for ANPP and N mineralization (Gower and Son 1992, Gower et al. 1993). Aber et al. (1991) summarized data from 18 of the 50 stands and used them to explore approaches to modeling dynamics of $\mathrm{N}$ saturation. Data for one oak stand at the University of Wisconsin (UW)-Madison Arboretum, the 17 specific stands at Cedar Creek, the two stands at Cloquet, and the one at Boulder Junction have not been previously published.

At the UW-Arboretum, 17 stands were studied within a 500 ha area on gently rolling terrain. Planted stands included eight sugar maple (Acer saccharum), one paper birch (Betula papyrifera), and four conifer stands, and there were four mature natural oak-dominated stands (Nadelhoffer et al. 1983, 1985, Fownes 1985, Lennon et al. 1985). Planted stands were on abandoned agricultural (plowed) lands and were 35-40 yr old at the time of measurements. The conifer stands were white pine (Pinus strobus), red pine (P. resinosa), a white and red pine mix, and white spruce (Picea glauca). The oak stands had been subject to periodic fires before European settlement, followed by postsettlement grazing and light cutting, but had never been plowed. These stands contained a dominant canopy of old red (Quercus rubra), white ( $Q$. alba), and/or black ( $Q$. velutina) oaks ( $>125 \mathrm{yr}$ old), with an admixture of younger, smaller sugar maple, red maple (A. rubrum), black cherry (Prunus serotina), and yellow birch ( $B$. alleghaniensis). All but one stand (a Mollisol) at the UW-Arboretum were on well-drained Alfisols derived from glacial deposits overlain by a loess cap. All soils had silt-loam texture $(0-10 \mathrm{~cm})$.

On Blackhawk Island (70 ha) located in the Wisconsin River, sites included eight mature unlogged forest stands (estimated age $>100 \mathrm{yr}$ ) across an edaphic and topographic gradient (Pastor et al. 1984). Stand types (and their associated soil types) included red and white pine (Entisol/Spodosol), red oak, white oak, and sugar maple (Alfisol), and hemlock (Tsuga canadensis)(Histosol). The pine-dominated stands were on sandy river terraces. The oak and maple stands were on higher landscape positions on soils of sandy clay loam to silty clay loam texture. The hemlock stand was located on a cliff on thin organic soil.

At the Coulee Experimental Forest, near Bangor in LaCrosse County, Wisconsin, five species were studied on post-agricultural land in 29-yr-old plantation stands, including two exotic conifers, Norway spruce (Picea abies) and European larch (Larix decidua) (Gower and Son 1992, Gower et al. 1993). The topography of the experimental forest is characterized by broad ridges dissected by gently to strongly sloping valleys. Soils of this region were formed primarily from windblown silt (loess) overlying dolomite or sandstone. Replicate plots were established in three replicate blocks of the five species monocultures, located on ridgetop and midto-lower slope positions within $2 \mathrm{~km}$ of each other. Soils are classified as fine-silty, mixed, mesic Typic Hapludalfs.

At Cedar Creek Natural History Area, Minnesota, 17 natural forest and woodland stands (estimated age $>60-80 \mathrm{yr}$ ) were studied across an array of sites ranging from wet lowland (hardwood and white cedar [Thuja occidentalis] forest) to dry upland (pine, maple and oak forest, and oak savanna). Soils on these sites had never been plowed, but many stands were likely subjected to periodic fire, grazing, and/or selective cutting until the 1930s. The Cedar Creek site is located on the Anoka Sand Plain. Soils there developed from deep (20 m) well-sorted glacial outwash of very uniform fine sand $(>90 \%)$. Local relief ranges up to $\approx 5 \mathrm{~m}$. The regional water table is at or near the soil surface in low-lying areas and is only several meters below the surface in the highest elevations. Due to this hydrology, topography, and the permeable soil materials, the study area is composed of diverse wetland and upland ecosystems that lie in proximity to one another. Upland soils were sandy Entisols and lowland soils were Histosols (Grigal and Homann 1994). At the Cloquet Forestry Center, in Cloquet, Minnesota, two $\approx 30$-yr-old trembling aspen (Populus tremuloides) stands were studied on sandy Entisols. These five study areas span a range of $\approx 460 \mathrm{~km}$ on a northwest-southeast transect from northeastern Minnesota to south-central Wisconsin. Near Boulder Junction, Wisconsin $(\approx 310 \mathrm{~km}$ due north of Madison), a 31-yr-old red pine plantation on the Northern Highlands State Forest was studied on a sandy Spodosol (Haynes and Gower 1995).

Although complete soil data are lacking for the sites, we can infer some differences in soil characteristics among sites from their taxonomic classification into soil orders. Our data included soils from 5 of the 11 soil orders (USDA 1975, Buol et al. 1980). Entisols are characterized as soils with little evidence of development, and in our case the very coarse texture of the soil materials has limited development. Typically, these soils have low water-holding characteristics, soil organic matter, base status, and cation exchange capacity. The Spodosols included in this study are physically and chemically similar to the Entisols, but Spodosols typically show more evidence of development, and specifically of movement of iron from surface to subsurface horizons. Alfisols, soils defined by movement of clay from the surface to subsurface horizons, have higher base status and finer texture, hence better water-holding properties, than the Entisols and Spodosols. Histosols are organic soils, with much different physical and chemical properties than mineral soils.

The study region has a cold temperate, continental climate. Mean annual temperature decreases from 
southeast to northwest along this transect, from $8.0^{\circ} \mathrm{C}$ in Madison, Wisconsin to $4.0^{\circ} \mathrm{C}$ at Cloquet, Minnesota. Mean annual precipitation varies less markedly among study areas (Table 1). For comparative purposes, stands were grouped by location, soil order, forest type, and stand origin (planted vs. natural). Mesic hardwood stands included primarily maple-dominated stands, but also included stands dominated by ash (Fraxinus), aspen, basswood (Tilia americana), or birch. Analyses for maple stands alone were not significantly different than those for all mesic hardwoods, and hence they are lumped throughout this paper.

For upland stands $(n=46)$, soil net $\mathrm{N}$ mineralization was measured seasonally over several incubation periods with the buried polyethylene bag technique (Nadelhoffer et al. 1983, Pastor et al. 1984) at Blackhawk Island, UW Arboretum, and Coulee Experimental Forest, and with the in situ tube method (Zak and Grigal 1991) at Cedar Creek, Cloquet, and Boulder Junction. Binkley and Hart (1989) thoroughly discuss these techniques and comparisons between these and related methods. In both techniques, net $\mathrm{N}$ mineralization is calculated based on the difference in $\mathrm{N}$ between extracts from initial and incubated soil samples. Both techniques provide an index of $\mathrm{N}$ availability that is sensitive to differences in soil microclimate. The number of replicate incubated samples per stand generally ranged from 7 to 10 (depending on time of year, study, and other factors), but was 15-20 (5 in each of 3 or 4 replicate plots per species) at Coulee Experimental Forest where replicate monoculture plots were used for each species (stand). Incubation periods were usually 4-6 wk during the growing season and longer in winter, and all periods were summed to estimate annual net mineralization values. For wetland sites $(n=4$, all at Cedar Creek), Grigal and Homann (1994) estimated N mineralization as a fixed proportion $(1.5 \%)$ of the periodically aerated peat soil. Overall results were similar with or without the wetland sites included in the database. For all sites, data are considered to represent an approximation of total net $\mathrm{N}$ mineralization, since the soil strata where a majority of mineralization occurs were sampled. For this reason, data on $\mathrm{N}$ mineralization for Blackhawk Island are consistent with those reported in Aber et al. (1991) and not those in Pastor et al. (1984). ANPP was measured by combining annual fine litterfall with estimates of wood production based on either allometric equations and 5- or 10-yr change in dbh (diameter at breast height) measured from annual ring widths obtained by tree coring (Pastor et al. 1984, Gower et al. 1993, Grigal and Homann 1994) or by annual DBH sampling (Cloquet). Detailed information about $\mathrm{N}$ mineralization, $\mathrm{N}$ litterfall, and ANPP measurements are available from these prior papers.

Data from Zak et al. (1989), Zak and Pregitzer (1990), and Pastor et al. (1993) were not included because potential rather than in situ $\mathrm{N}$ mineralization was measured (Zak et al. 1989); $\mathrm{N}$ mineralization analyses were restricted to superficial soil horizons (Zak and Pregitzer 1990, Pastor et al. 1993); and/or because the measure of wood production was not directly comparable with the other studies (Zak et al. [1989] and Zak and Pregitzer [1990] used standing biomass divided by stand age, which underestimates total stem production over the stand age since tree and branch death are ignored). We are aware of no other data sets from this region that could be used in this analysis, an important point since we consider this to be a general, not a selective, comparison.

Analyses of variance, linear, and multiple regression were applied using the JMP statistical program (SAS 1994). Pairwise comparisons among study areas, soil types, vegetation types, stand history, and combinations of these groupings, were made with Student's $t$ tests. Analyses of covariance were made in which study area was included as a nominal effect along with any of several continuous factors (e.g., ANPP, N mineralization, etc.) and their crossed effect (interaction). Analyses of covariance were also used to test for slope and intercept differences in regression relationships among different forest type and soil groupings.

\section{RESULTS}

When all closed-canopy forest stands are examined, study areas differed in average ANPP, $\mathrm{N}$ mineralization, and litterfall $\mathrm{N}$ cycling (Table 2). The plantation stands at Coulee and the stands at UW-Arboretum had greater average ANPP $\left(\approx 8.5-9.0 \mathrm{Mg} \cdot \mathrm{ha}^{-1} \cdot \mathrm{yr}^{-1}\right)$ and $\mathrm{N}$ mineralization $\left(\approx 71-75 \mathrm{~kg} \cdot \mathrm{ha}^{-1} \cdot \mathrm{yr}^{-1}\right)$, and those at Cedar Creek had lower ANPP (6.5 Mg.ha ${ }^{-1} \cdot \mathrm{yr}^{-1}$ ) and $\mathrm{N}$ mineralization $\left(57 \mathrm{~kg} \cdot \mathrm{ha}^{-1} \cdot \mathrm{yr}^{-1}\right)$. However, within and across study areas, sites varied in forest type, soil type and texture, and land use history. Collectively these variables, plus mean annual temperature, explained most of the variation in $\mathrm{N}$ mineralization and ANPP among stands.

Using analyses of covariance, study area effects were not significant for any response variable. As an example, in analysis of covariance for ANPP, study area was not a significant variable, whereas $\mathrm{N}$ mineralization and percentage silt plus clay were $(P<0.05)$. Thus, response variables were largely related to measured parameters and not to unknown study area factors. Examination of differences among forest types on similar soils (and the reverse) provides a clearer method of comparing ANPP and N mineralization as a function of soil and vegetation attributes.

Average annual net $\mathrm{N}$ mineralization, ANPP, and litterfall $\mathrm{N}$ cycling differed significantly among the three vegetation types and two stand origins (Table 3 ). In natural forests, all of these were greater in oak than in mesic hardwood or conifer stands, respectively $(79,66$, and $48 \mathrm{~kg} \cdot \mathrm{ha}^{-1} \cdot \mathrm{yr}^{-1}$ for $\mathrm{N}$ mineralization; 41,39 , and $34 \mathrm{~kg} \cdot \mathrm{ha}^{-1} \cdot \mathrm{yr}^{-1}$ for litterfall $\mathrm{N}$; and $8.1,7.3$, and 6.5 $\mathrm{Mg} \cdot \mathrm{ha}^{-1} \cdot \mathrm{yr}^{-1}$ for ANPP). For planted stands, $\mathrm{N}$ mineralization, ANPP, and litterfall $\mathrm{N}$ were not signifi- 
TABLE 2. Mean ( $\pm 1 \mathrm{SE}$ ) aboveground net primary production (ANPP), annual net $\mathrm{N}$ mineralization, and annual total litterfall $\mathrm{N}$ for closed-canopy forests in Wisconsin and Minnesota, grouped by location, and soil type $\times$ stand origin (data shown only for locations or soil/ stand origin types with at least five stands). Columns without letters in common differed significantly $(P<0.05)$ using pairwise comparisons, Student's $t$ test.

\begin{tabular}{|c|c|c|c|c|}
\hline Sample & $n$ & $\begin{array}{c}\text { ANPP } \\
\left(\mathrm{Mg} \cdot \mathrm{ha}^{-1} \cdot \mathrm{yr}^{-1}\right)\end{array}$ & $\begin{array}{l}\mathrm{N} \text { mineralized } \\
\left(\mathrm{kg} \cdot \mathrm{ha}^{-1} \cdot \mathrm{yr}^{-1}\right)\end{array}$ & $\begin{array}{c}\text { Litterfall N } \\
\left(\mathrm{kg} \cdot \mathrm{ha}^{-1} \cdot \mathrm{yr}^{-1}\right)\end{array}$ \\
\hline \multicolumn{5}{|l|}{ Location } \\
\hline UW Arboretum & 17 & $8.5(0.5) \mathrm{a}$ & $75(8) \mathrm{a}$ & $33(2) b$ \\
\hline Blackhawk Island & 8 & $7.5(0.7) \mathrm{ab}$ & $73(12) \mathrm{a}$ & $28(3) b$ \\
\hline Coulee $\dagger$ & 5 & $9.0(0.6)$ a & $71(13) \mathrm{a}$ & 34 (3) ab \\
\hline Cedar Creek & 15 & $6.5(0.3) b$ & $57(5) \mathrm{a}$ & $43(2) \mathrm{a}$ \\
\hline \multicolumn{5}{|l|}{ Soil type/stand origin } \\
\hline Alfisols/planted & 17 & $7.9(0.3) b$ & $64(6) b$ & $31(1) \mathrm{a}$ \\
\hline Alfisols/natural & 9 & $10.1(0.6) \mathrm{a}$ & $105(7) \mathrm{a}$ & 39 (3) a \\
\hline Entisols/natural $\ddagger$ & 14 & $6.2(0.3) \mathrm{c}$ & $51(5) b$ & $39(4) \mathrm{a}$ \\
\hline Histosols/natural & 5 & $6.6(0.7) b c$ & $53(11) \mathrm{b}$ & $38(8) \mathrm{a}$ \\
\hline
\end{tabular}

$\dagger$ Mean values excluding two exotic species were $\approx 7-10 \%$ lower.

\$ Mean values including two oak savannas were $\approx 10 \%$ lower.

cantly lower in conifers than hardwoods. For both natural and planted stands, conifers had significantly lower canopy foliage efficiency than hardwoods and a trend toward higher ANPP/litterfall $\mathrm{N}$ and ANPP/mineralized N.

Across all stands, Alfisol soils averaged $\approx 70 \%$ silt plus clay (standard deviation of $20 \%$ ) whereas the Entisols averaged $\approx 16 \%$ silt plus clay (standard deviation of $8 \%$ ). The Histosol and Spodosol soils used in this study were also sandy. For natural stands, ANPP and $\mathrm{N}$ mineralization were greater on average (pooling all forest types and locations) on the Alfisols than on Histosols or Entisols (Table 2). A similar pattern was observed when forest types were examined separately (Figure 1). For natural oak or mesic hardwood stands, ANPP and net $\mathrm{N}$ mineralization were greater on the finer textured Alfisols $\left(\approx 10 \mathrm{Mg} \cdot \mathrm{ha}^{-1} \cdot \mathrm{yr}^{-1}\right.$ and $\approx 105$ $\left.\mathrm{kg} \cdot \mathrm{ha}^{-1} \cdot \mathrm{yr}^{-1}\right)$ than on the sandy Entisols $(\approx 6$ $\mathrm{Mg} \cdot \mathrm{ha}^{-1} \cdot \mathrm{yr}^{-1}$ and $\left.\approx 50 \mathrm{~kg} \cdot \mathrm{ha}^{-1} \cdot \mathrm{yr}^{-1}\right)$. Hardwood stands planted on Alfisols had values intermediate between these groups. For evergreen conifers, ANPP and net N mineralization were greater in plantations on Alfisols $\left(8.3 \mathrm{Mg} \cdot \mathrm{ha}^{-1} \cdot \mathrm{yr}^{-1}\right.$ and $\left.61 \mathrm{~kg} \cdot \mathrm{ha}^{-1} \cdot \mathrm{yr}^{-1}\right)$ than in natural stands on Entisols (6.2 Mg.ha- $\mathrm{ha}^{-1} \cdot \mathrm{yr}^{-1}$ and 53 $\left.\mathrm{kg} \cdot \mathrm{ha}^{-1} \cdot \mathrm{yr}^{-1}\right)$. Hardwood and evergreen conifer stands did not differ significantly in ANPP or $\mathrm{N}$ mineralization on comparable soils and stand origin: they differed neither as plantations on Alfisols (both $\approx 8$ $\mathrm{Mg} \cdot \mathrm{ha}^{-1} \cdot \mathrm{yr}^{-1}$ and $\approx 60 \mathrm{~kg} \cdot \mathrm{ha}^{-1} \cdot \mathrm{yr}^{-1}$ ) nor as natural stands on Entisols (both $\approx 6 \mathrm{Mg} \cdot \mathrm{ha}^{-1} \cdot \mathrm{yr}^{-1}$ and $\approx 50$ $\left.\mathrm{kg} \cdot \mathrm{ha}^{-1} \cdot \mathrm{yr}^{-1}\right)$.

There was a significant linear relationship between ANPP and annual $\mathrm{N}$ mineralization for all stands $(P<$ 0.001, $r^{2}=0.54$ ) (Fig. 2). ANPP was also linearly correlated with total $\mathrm{N}$ cycled in annual litterfall $(P<$ $0.001, r^{2}=0.24$ ) (Fig. 2), but the relationship was not as strong as with $\mathrm{N}$ mineralization. Of the 50 stands, an exotic conifer (Norway spruce) plantation at Coulee with high ANPP and moderately low $\mathrm{N}$ mineralization was a statistical outlier (according to Mahalanobis distance criteria). Omitting this species (or both exotic species, Norway spruce and European larch), the relationship between ANPP and annual $\mathrm{N}$ mineralization was stronger $\left(P<0.001, r^{2}=0.63\right)$. The ANPP-N mineralization relationship was significant for closedcanopy native evergreen conifer $\left(r^{2}=0.53, n=14\right)$,

TABLE 3. Mean ( $\pm 1 \mathrm{SE}$ ) aboveground net primary production (ANPP), annual net $\mathrm{N}$ mineralization, annual total litterfall $\mathrm{N}$, foliage efficiency (ANPP/foliage mass), ANPP/N mineralized, and ANPP/(litterfall N) for native closed-canopy forests in Wisconsin and Minnesota (pooled across study areas). Within columns, values without letters in common differed significantly $(P<0.05)$ using pairwise comparisons, Student's $t$ test (letters with dagger were significantly different at $P$ $<0.10)$.

\begin{tabular}{|c|c|c|c|c|c|c|c|c|}
\hline Vegetation type & $\begin{array}{l}\text { Stand } \\
\text { origin }\end{array}$ & $n$ & 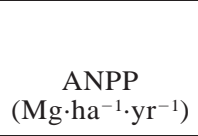 & $\begin{array}{l}\mathrm{N} \text { miner- } \\
\text { alized } \\
\left(\mathrm{kg} \cdot \mathrm{ha}^{-1}\right. \\
\left.\cdot \mathrm{yr}^{-1}\right)\end{array}$ & $\begin{array}{c}\text { Litterfall N } \\
\left(\mathrm{kg} \cdot \mathrm{ha}^{-1}\right. \\
\left.\cdot \mathrm{yr}^{-1}\right)\end{array}$ & $\begin{array}{l}\text { Foliage } \\
\text { efficiency } \\
(\mathrm{kg} / \mathrm{kg})\end{array}$ & $\begin{array}{c}\text { ANPP/N } \\
\text { mineralized } \\
(\mathrm{kg} / \mathrm{kg})\end{array}$ & $\begin{array}{c}\text { ANPP/ } \\
\text { litterfall N } \\
(\mathrm{kg} / \mathrm{kg})\end{array}$ \\
\hline Oak & Natural & 14 & $8.1(0.7) \mathrm{a}$ & $79(8) \mathrm{a}$ & $41(2) \mathrm{a}$ & $2.36(0.1) \mathrm{a}$ & $111(10) b$ & 205 (19) ab \\
\hline Mesic hardwood & Natural & 8 & $7.3(0.6) \mathrm{ab}$ & $66(11) a b$ & $39(4) \mathrm{a} \dagger$ & $2.40(0.1) \mathrm{a}$ & 130 (19) ab & $193(20) \mathrm{b}$ \\
\hline Evergreen conifer & Natural & 7 & $6.5(0.5) \mathrm{b} \dagger$ & $48(7) b$ & $34(6) a b$ & $0.72(0.1) b$ & $145(17) \mathrm{a} \dagger$ & $221(39) \mathrm{b}$ \\
\hline Oak & Planted & 1 & 8.9 & 55 & 34 & 2.39 & 161 & 261 \\
\hline Mesic hardwood & Planted & 9 & $7.4(0.3) \mathrm{ab}$ & $62(9) \mathrm{ab}$ & $30(1) b$ & $2.14(0.1) \mathrm{a}$ & 140 (19) ab & $245(11) b$ \\
\hline Evergreen conifer & Planted & 8 & $8.3(0.5) \mathrm{a}$ & $58(7) \mathrm{b}^{\dagger}$ & 27 (3) b & $0.87(0.1) b$ & $155(18) \mathrm{a}$ & $334(49)$ a \\
\hline
\end{tabular}

$\ddagger$ Mean values including two oak savannas were $\approx 10 \%$ lower. 

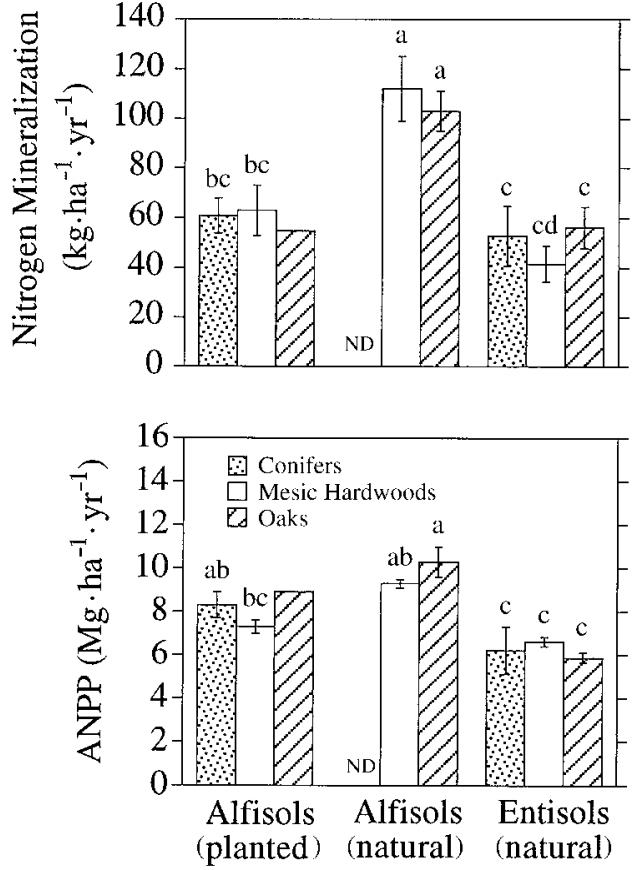

FIG. 1. Mean ( $\pm 1 \mathrm{SE})$ annual net $\mathrm{N}$ mineralization rate and aboveground net primary production (ANPP) for conifer, mesic hardwoods, and oak stands, planted or natural, on Alfisol and Entisol soils at six study areas in Wisconsin and Minnesota, USA. There were no data for natural conifer stands on Alfisols (ND). Values with no common letters were significantly different (pairwise comparison, using Student's $t$ test, $P<0.05$ ). Only one planted oak stand was sampled, so no comparisons were made for this class.

mesic hardwood $\left(r^{2}=0.58, n=17\right)$, and oak $\left(r^{2}=\right.$ $0.69, n=15)$ groups, and (separate slopes) analyses showed no significant difference between the regressions for these three groups $(P>0.25)$. There were also no significant differences between vegetation groups (e.g., conifers vs. hardwoods) in their ANPPannual $\mathrm{N}$ litterfall relationships. Similarly, the regres-

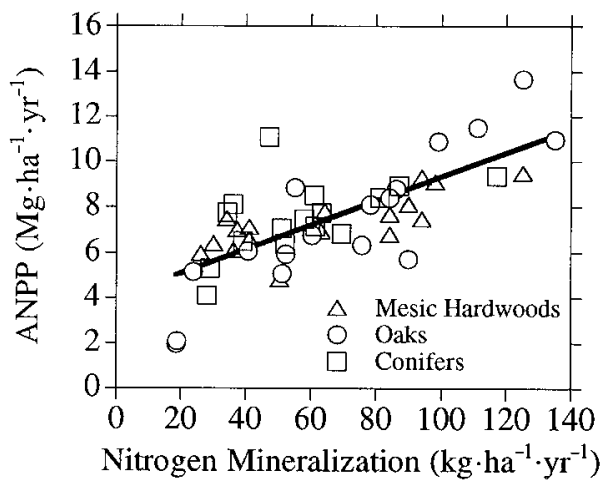

sion relationships between ANPP and N mineralization were significant $\left(P<0.05, n=8-17, r^{2}\right.$ ranged from 0.4 to 0.9$)$ but not different $(P>0.25)$ at Cedar Creek, Blackhawk Island, and the UW Arboretum (analysis not done for other study areas due to low sample sizes).

However, soils and stand origin differences, which were important in contrasts of mean values, were also important in terms of the relationship between ANPP and $\mathrm{N}$ mineralization. The relationship of ANPP to $\mathrm{N}$ mineralization differed significantly $(P<0.05)$ for natural vs. planted stands (Fig. 3). This relationship was strong for the 31 natural stands $\left(P<0.001, r^{2}=0.73\right)$ and had a significantly lower slope $(P<0.05$, separate slopes analysis) for the planted stands. The ANPP-N mineralization relationship differed significantly $(P<$ 0.05 ) in intercept but not slope for finer textured Alfisols vs. either sandy Entisols (Fig. 3), or vs. all other soil types lumped together (data not shown). At any given level of $\mathrm{N}$ mineralization, forest stands on Alfisols had a greater ANPP than on other soil types. Consequently, high ANPP for forest stands on Alfisols (Table 2, Fig. 1) resulted not only from high average net $\mathrm{N}$ mineralization rates, but from high ANPP per available $\mathrm{N}$ as well. As noted above, differences in texture between the Alfisol and Entisol soils used in this study were large and consistent. Thus, differences in water retention characteristics (linked to the marked differences in soil texture) among soils may play a role in determining both mineralization of soil $\mathrm{N}$ and its use.

We explored additional ways of examining study area, soil, climate, and forest type effects on $\mathrm{N}$ mineralization and ANPP. Multiple regression analyses for $\mathrm{N}$ mineralization showed that neither study area nor forest type (nor interaction of any variables) were significant in models for all stands, native species, or natural stands, but that total litterfall $\mathrm{N}$, and mean annual temperature (and depending on the data subset, soil texture [percentage silt plus clay]) were significant

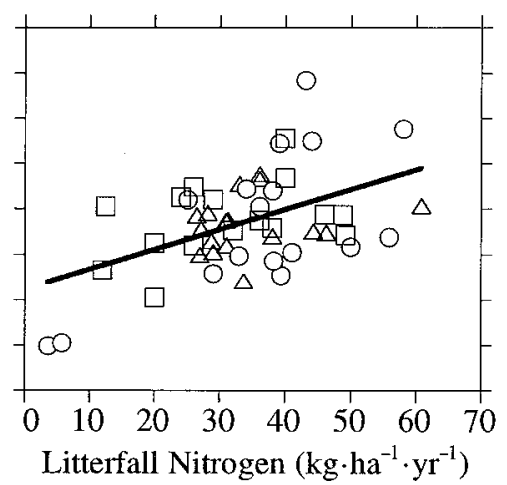

FIG. 2. Relationships between aboveground net primary production $\left(\mathrm{Mg} \cdot \mathrm{ha}^{-1} \cdot \mathrm{yr}^{-1}\right)$ and both annual net $\mathrm{N}$ mineralization $\left(\mathrm{kg} \cdot \mathrm{ha}^{-1} \cdot \mathrm{yr}^{-1}\right)$ and annual $\mathrm{N}$ in litterfall $\left(\mathrm{kg} \cdot \mathrm{ha}^{-1} \cdot \mathrm{yr}^{-1}\right)$ for broad-leaved deciduous oaks, mesic hardwoods, and needle-leaved conifers. The combined regression relationships for all stands $(n=50)$ : ANPP $=4.04+0.053($ mineralized $\mathrm{N}), r^{2}=0.54$, $P<0.001 ;$ ANPP $=4.44+0.088\left(\right.$ litterfall N), $r^{2}=0.24, P<0.001$. For native species only $(n=48)$, ANPP $=3.77+$ $0.056($ mineralized $\mathrm{N}), r^{2}=0.63, P<0.001$. 


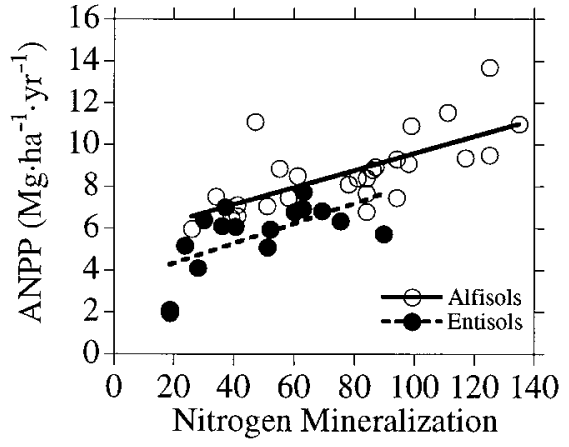

$\left(\mathrm{kg} \cdot \mathrm{ha}^{-1} \cdot \mathrm{yr}^{-1}\right)$

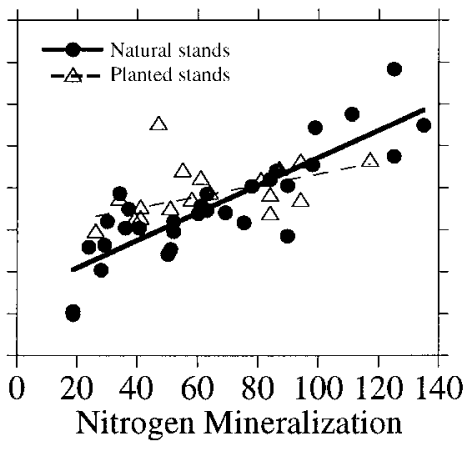

$\left(\mathrm{kg} \cdot \mathrm{ha}^{-1} \cdot \mathrm{yr}^{-1}\right)$

FIG. 3. Relationships between aboveground net primary production $\left(\mathrm{Mg} \cdot \mathrm{ha}^{-1} \cdot \mathrm{yr}^{-1}\right)$ and annual net $\mathrm{N}$ mineralization $\left(\mathrm{kg} \cdot \mathrm{ha}^{-1} \cdot \mathrm{yr}^{-1}\right)$ for natural vs. planted stands, and for stands on Alfisol soils and Entisol soils. The regression relationship for natural stands $(n=31)$, ANPP $=2.87+0.066($ mineralized $\mathrm{N}), r^{2}=0.73, P<0.001$; for planted stands $(n=19)$, ANPP $=6.71+0.019\left(\right.$ mineralized N), $r^{2}=0.16, P<0.09$; planted stands without Norway spruce $(n=18)$, ANPP $=6.19+$ 0.024(mineralized N), $r^{2}=0.40, P<0.005$. The regression relationship for Alfisols $(n=26)$, ANPP $=5.42+0.042(\mathrm{~min}-$ eralized N), $r^{2}=0.49, P<0.001$; for Entisols $(n=16)$, ANPP $=3.40+0.048($ mineralized $\mathrm{N}), r^{2}=0.41, P<0.01$; for Alfisols without Norway spruce, ANPP $=4.80+0.048($ mineralized $\mathrm{N}), r^{2}=0.64, P<0.001$.

variables in the model. In a multiple regression of annual soil $\mathrm{N}$ mineralization for the 27 natural stands (Fig. 4), $81 \%$ of the variance in $\mathrm{N}$ mineralization rate was explained by total litterfall $\mathrm{N}\left(P<0.001, F_{1,23}=\right.$ 25.1), percentage silt plus clay $\left(P<0.005, F_{1,23}=\right.$ 14.0), and mean annual temperature $\left(P<0.01, F_{1,23}=\right.$ 8.3). The combined model was not as good for all stands $\left(r^{2}=0.44\right)$, respectively, and only litterfall $\mathrm{N}$ $\left(P<0.001, F_{1,44}=21.0\right)$ and annual temperature $(P$ $\left.<0.05, F_{1,44}=4.6\right)$ were significant.

Multiple regression analyses for ANPP showed that only $\mathrm{N}$ mineralization rate and soil texture (percentage silt plus clay) were significant. Multiple regressions of ANPP on soil texture and annual $\mathrm{N}$ mineralization rate explained 65,74 , and $83 \%$ of the variance in ANPP for all stands, native species, and natural stands, respectively. For the latter regression (Fig. 4), both annual $\mathrm{N}$ mineralization $\left(P<0.001, F_{1,24}=17.9\right)$ and soil texture $\left(P<0.005, F_{1,24}=11.6\right)$ contributed substantially to explaining variation in ANPP. Soil properties and processes (Tables 2 and 3, Figs. 1 and 3) thus explained many of the study area and forest type differences in ANPP (Tables 2 and 3, Figs. 1-3).

Wood production was positively related to annual $\mathrm{N}$ mineralization $\left(P<0.001, r^{2}=0.50,0.55\right.$, and 0.63 for the total, native species, and natural stand data sets, respectively) and very weakly related to annual litterfall $\mathrm{N}$ using any data subset $\left(P<0.05, r^{2} \leq 0.15\right)$ (Fig. $5)$. In contrast, foliage production was slightly better correlated to annual litterfall $\mathrm{N}$ than mineralized $\mathrm{N}$ using either the complete data set $\left(r^{2}=0.34\right.$ vs. 0.26$)$ (Fig. $6)$, or the natural stand data $\left(r^{2}=0.58\right.$ vs. 0.50$)$. In none of the above relationships were regression slopes or intercepts significantly different for vegetation types, for conifer vs. hardwood groups (or for evergreen vs. deciduous groups, i.e., moving larch from the
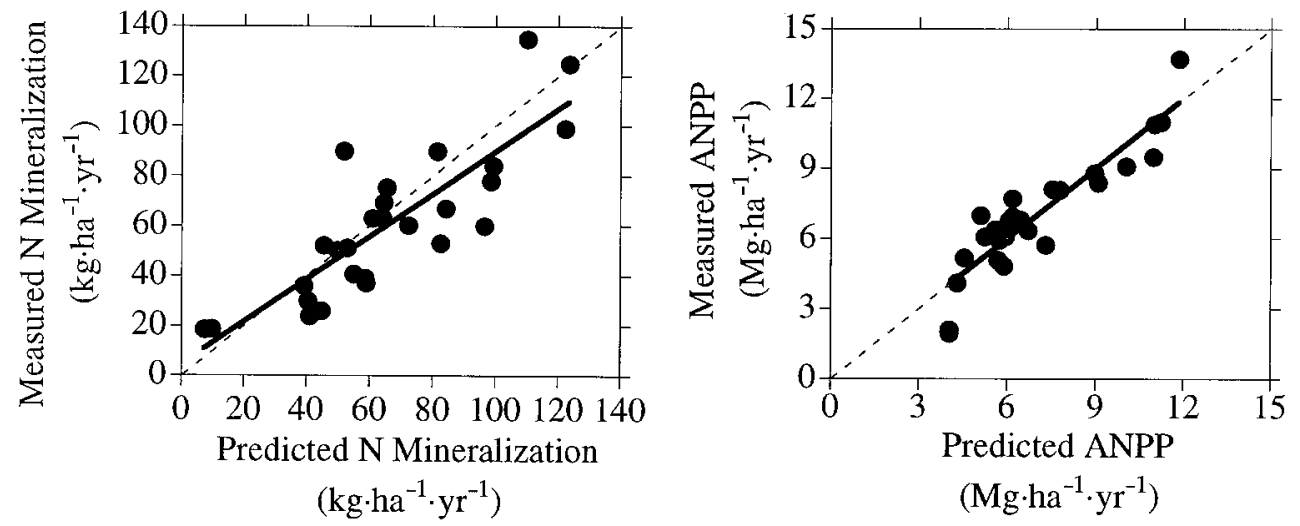

FIG. 4. Measured vs. predicted $\mathrm{N}$ mineralization and ANPP using multiple regression relationships: annual $\mathrm{N}$ mineralization $=-53.4+1.17($ litterfall $\mathrm{N})+0.56(\%$ silt + clay $)+9.47($ mean annual temperature $)$ with $r^{2}=0.81$ and $P<0.01$ for each term; ANPP $=2.93+0.042$ (annual $\mathrm{N}$ mineralization) $+0.041\left(\%\right.$ silt + clay) with $r^{2}=0.83$ and $P<0.01$ for each term. Both the measured vs. predicted lines $(-)$, and the $1: 1$ lines $(---)$, are shown. 

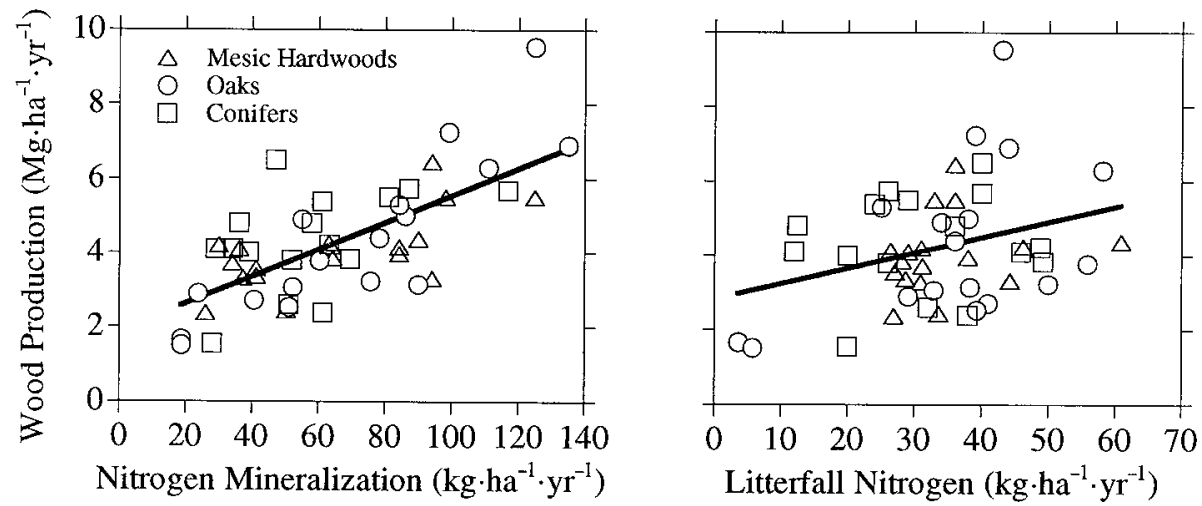

FIG. 5. Relationship between annual wood production $\left(\mathrm{Mg} \cdot \mathrm{ha}^{-1} \cdot \mathrm{yr}^{-1}\right)$ and both annual net $\mathrm{N}$ mineralization $\left(\mathrm{kg} \cdot \mathrm{ha} \mathrm{a}^{-1} \cdot \mathrm{yr} \mathrm{r}^{-1}\right)$ and annual $\mathrm{N}$ in litterfall $\left(\mathrm{kg} \cdot \mathrm{ha}^{-1} \cdot \mathrm{yr}^{-1}\right)$ for broad-leaved deciduous oaks, mesic hardwoods, and needle-leaved conifers. The combined regression relationships for all stands $(n=50)$ : wood production $=1.88+0.037($ mineralized $\mathrm{N}), r^{2}=0.50, P$ $<0.001$; wood production $=2.81+0.042\left(\right.$ litterfall N), $r^{2}=0.10, P<0.05$. For native species only $(n=48)$, wood production $=1.72+0.038($ mineralized $\mathrm{N}), r^{2}=0.55, P<0.001$.

conifer to the deciduous group). All regression relationships explored between ANPP and its components and measures of $\mathrm{N}$ availability were stronger for the natural stand data set than either the planted stand or the total data set.

Annual litterfall $\mathrm{N}$ cycling was significantly but roughly correlated to annual $\mathrm{N}$ mineralization $(P<$ $0.01, r^{2}=0.24$ and 0.27$)$ using the complete data set (Fig. 7) or natural stand data, respectively. Among all stands, annual aboveground litterfall $\mathrm{N}$ represented $\approx 30-70 \%$ of annual $\mathrm{N}$ mineralization. Foliage efficiency (ANPP/foliage mass) was positively related to annual $\mathrm{N}$ mineralization rates in both evergreen conifers and deciduous hardwoods, and at any given $\mathrm{N}$ mineralization rate, foliage efficiency was twice as great in the deciduous group (Table 3). Two measures of vegetation $\mathrm{N}$ use efficiency (ANPP per either litterfall $\mathrm{N}$ or mineralized $\mathrm{N}$ ) suggest that $\mathrm{N}$ use efficiency decreases with increasing $\mathrm{N}$ cycling and availability (Fig. 8). However, no relationship exists when ANPP/ litterfall $\mathrm{N}$ is regressed against annual $\mathrm{N}$ mineralization (Fig. 8); because these two variables are based on independent measures, this is a preferred analysis, and suggests that $\mathrm{N}$ use efficiency may in fact not be related to $\mathrm{N}$ availability. The correlation of ANPP/mineralized $\mathrm{N}$ vs. annual litterfall $\mathrm{N}$ was also not significant (data not shown).

\section{DISCUSSION}

What light do these analyses shed on local and regional controls of $\mathrm{N}$ cycling and productivity in cold temperate forests? From previous work it has been shown that climate (Van Cleve et al. 1983), soils/vegetation/landform gradients (Pastor et al. 1984, Zak et al. 1986) and vegetation type (Gower and Son 1992) all may influence annual $\mathrm{N}$ mineralization and/or ANPP. After standardizing for soil differences, productivity of the natural closed-canopy ecosystems in this study was roughly comparable across study areas and/or across forest types. The fundamental differences among stands and study areas in this study were related to parent material, land use history, temperature, and potentially to feedbacks between parent material, soil processes and plant productivity (Gosz 1981, Pastor and Post 1986, Aber et al. 1991). According to this line of thought, better substrate leads to high productivity, partly in the form of detritus, which leads to high $\mathrm{N}$ cycling, hence leading to higher productivity, until another resource limits growth. This could explain in part the tighter linkage of $\mathrm{N}$ mineralization, litterfall $\mathrm{N}$, and productivity on older natural stands (where these interactions have had more time to develop) than on younger planted stands, especially in cases where species were planted on atypical sites (such as exotics). The six study areas span a relatively modest range of climate variation. Temperature was significantly related to mean annual $\mathrm{N}$ mineralization, but had no direct significant effect on ANPP (in multiple regression). Across a larger climatic range one would expect that the proportional influence of climate on soil net $\mathrm{N}$ mineralization processes would be more significant (Flanagan and Van Cleve 1983, Van Cleve et al. 1983), as would direct biophysical controls on ANPP (McMurtrie et al. 1994).

\section{Control of $N$ mineralization rates and ANPP}

From these analyses of nonrandomly selected Wisconsin and Minnesota sites, it appears that intrinsic soil properties exert a large influence on $\mathrm{N}$ mineralization rates, and that $\mathrm{N}$ availability, plus other features of finer textured soils (such as water-holding capacity), control ANPP. Major soil orders provided the most consistent contrast of $\mathrm{N}$ mineralization and ANPP, with finer textured Alfisols having greater levels of both than coarser textured Entisols, both among and within forest types, and soil texture was one of two significant factors re- 

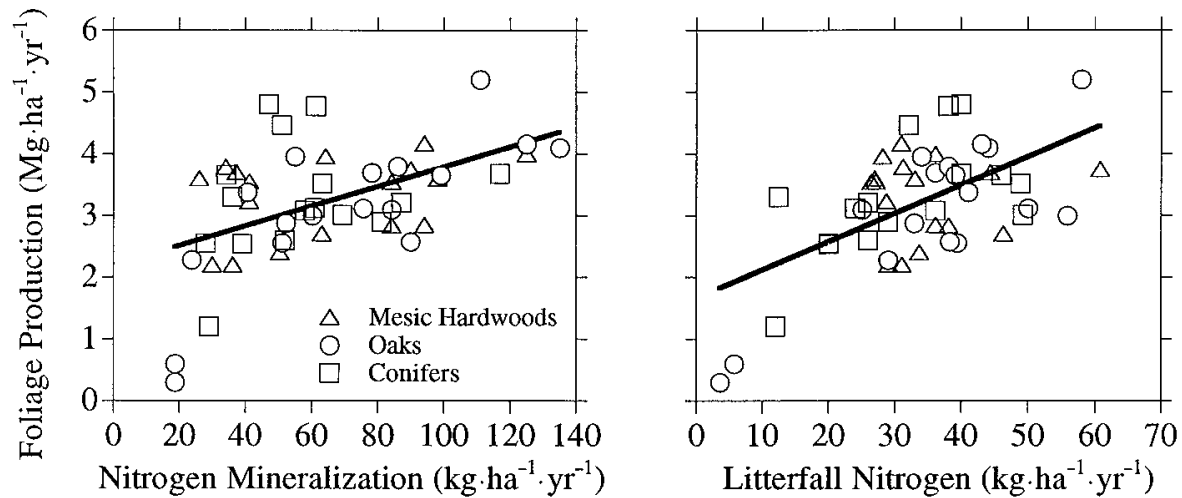

FIG. 6. Relationship between annual foliage production $\left(\mathrm{Mg} \cdot \mathrm{ha}^{-1} \cdot \mathrm{yr}^{-1}\right)$ and both annual net $\mathrm{N}$ mineralization $\left(\mathrm{kg} \cdot \mathrm{ha} \mathrm{a}^{-1} \cdot \mathrm{yr} \mathrm{r}^{-1}\right)$ and annual $\mathrm{N}$ in litterfall $\left(\mathrm{kg} \cdot \mathrm{ha}^{-1} \cdot \mathrm{yr}^{-1}\right)$ for broad-leaved deciduous oaks, mesic hardwoods, and needle-leaved conifers. The combined regression relationships for all stands $(n=50)$ : foliage production $=2.19+0.016($ mineralized $\mathrm{N}), r^{2}=0.26, P$ $<0.001$; foliage production $=1.65+0.046($ litterfall $\mathrm{N}), r^{2}=0.34, P<0.001$. For native species only, foliage production $=2.08+0.017($ mineralized $\mathrm{N}), r^{2}=0.30, P<0.001$.

lated to ANPP or N mineralization rates using multiple regression.

The evidence of potential vegetation feedbacks on $\mathrm{N}$ mineralization and ANPP was less consistent. Annual litterfall $\mathrm{N}$ was a significant factor related to annual $\mathrm{N}$ mineralization in multiple regression (although the relationship is clearly not unidirectional), and forest types with higher litterfall $\mathrm{N}$ also had higher $\mathrm{N}$ mineralization. However, forest types (natural stands or planted) did not consistently differ in $\mathrm{N}$ mineralization, litterfall N, or ANPP when compared on comparable soils. Some previous studies have documented greater $\mathrm{N}$ mineralization rates in mesic hardwood (largely maple dominated) than in oak stands in Michigan and Wisconsin (Pastor et al. 1984, Zak et al. 1986, Zak and Pregitzer 1990, Walters and Reich 1997). These four studies examined differences in productivity and $\mathrm{N}$ cy-

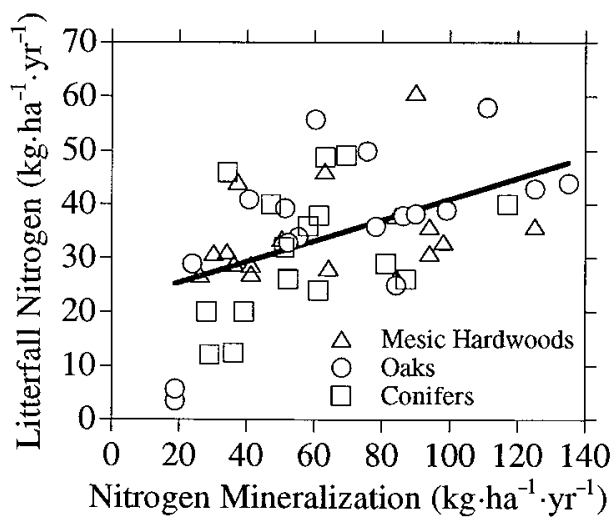

FIG. 7. Relationship between annual litterfall $\mathrm{N}$ $\left(\mathrm{kg} \cdot \mathrm{ha}^{-1} \cdot \mathrm{yr}^{-1}\right)$ and annual net $\mathrm{N}$ mineralization $\left(\mathrm{kg} \cdot \mathrm{ha}^{-1} \cdot \mathrm{yr}^{-1}\right)$ for broad-leaved deciduous oaks, mesic hardwoods, and needle-leaved conifers: litterfall $\mathrm{N}=21.5+0.20$ (mineralized $\mathrm{N}), r^{2}=0.24, P<0.001$. For a significant quadratric fit, litterfall $\mathrm{N}=7.67+0.67($ mineralized $\mathrm{N})-0.0033($ mineralized $\mathrm{N})^{2}, r^{2}=0.31, P<0.001$. cling among forest ecosystems that represented integrated landform, soil, and vegetation units, and thus it was impossible to separate whether differences were due to each or all of these factors. Nonetheless, differences in litter quality, largely in relation to lignin: $\mathrm{N}$ content, were highlighted as potentially important factors. Moreover, an experimental study of different tree species planted on similar soils also found strong feedback effects on $\mathrm{N}$ mineralization after $30 \mathrm{yr}$, and differences in lignin: $\mathrm{N}$ content of litter were again significantly related to differences in $\mathrm{N}$ mineralization (Gower and Son 1992). There were large differences in net $\mathrm{N}$ mineralization rates associated with successional changes in Alaskan vegetation and soils from year 107 (poplar) to year 184 (white spruce) in a chronosequence study (Van Cleve et al. 1993). Studies with herbaceous species have shown striking species effects on $\mathrm{N}$ mineralization rates after even shorter time periods (Wedin and Tilman 1990, Van Vuuren et al. 1992). In contrast, the data synthesized in this paper give no indication of consistent differences in average $\mathrm{N}$ mineralization rates for oaks, other hardwood species, or evergreen conifers on comparable soil groups. Other studies of adjacent hardwood-conifer stands on similar soils have also found minor or no differences in annual net $\mathrm{N}$ mineralization rates (Mladenoff 1987; M. F. Tobin and P. B. Reich, unpublished data).

How can the data analyses in this paper be reconciled with these other studies showing strong feedback effects of vegetation type on $\mathrm{N}$ cycling, and with several well-recognized models? Pastor and Post (1986) and Aber et al. (1991) proposed models that explain longterm changes in $\mathrm{N}$ mineralization as a function of changes in vegetation composition (and associated litter and decomposition characteristics), with soil $\mathrm{N}$ and water availability driving vegetation composition. Data for the 50 stands in this study are not inconsistent with their broadest hypotheses about vegetation-soil feed- 

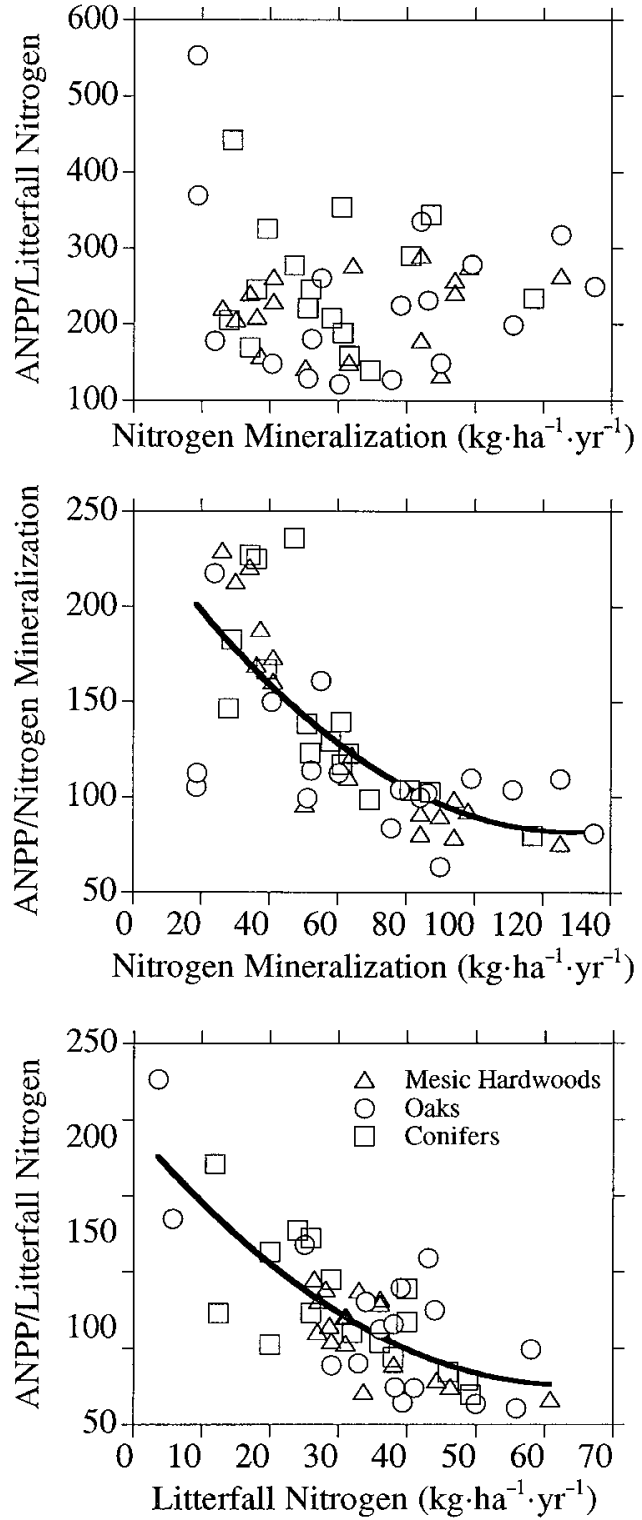

FIG. 8. Relationships for broad-leaved deciduous oaks, mesic hardwoods, and needle-leaved conifers, between: (bottom) ANPP/annual litterfall $\mathrm{N}\left(\mathrm{kg} \cdot \mathrm{ha}^{-1} \cdot \mathrm{yr}^{-1}\right)$ and annual litterfall $\mathrm{N}\left(\mathrm{kg} \cdot \mathrm{ha}^{-1} \cdot \mathrm{yr}^{-1}\right)$ [ANPP/annual litterfall $\mathrm{N}=581.4-$ $14.8($ litterfall $\left.\mathrm{N})+0.128(\text { litterfall } \mathrm{N})^{2}, r^{2}=0.63, P<0.001\right]$; (middle) ANPP/annual net mineralized $\mathrm{N}\left(\mathrm{kg} \cdot \mathrm{ha}^{-1} \cdot \mathrm{yr}^{-1}\right)$ and annual net mineralized $\mathrm{N}\left(\mathrm{kg} \cdot \mathrm{ha}^{-1} \cdot \mathrm{yr}^{-1}\right)$ [ANPP/annual net mineralized $\mathrm{N}=244.7-2.54($ mineralized $\mathrm{N})+0.0099(\min -$ eralized $\left.\mathrm{N})^{2}, r^{2}=0.54, P<0.001\right]$; and (top) ANPP/annual litterfall $\mathrm{N}\left(\mathrm{kg} \cdot \mathrm{ha}^{-1} \cdot \mathrm{yr}^{-1}\right)$ and annual net mineralized $\mathrm{N}$ $\left(\mathrm{kg} \cdot \mathrm{ha}^{-1} \cdot \mathrm{yr}^{-1}\right)$, not significant.

backs (ignoring vegetation type), but are inconsistent with the idea of strong differential vegetation type-soil feedbacks, at least in the Lake States region. Over extended time periods (several hundreds of years or more; Pastor and Post 1986, Aber et al. 1991) feedbacks between vegetation (regardless of kind) and soils may have resulted in differences in $\mathrm{N}$ mineralization and
ANPP seen across soils groups in these 50 stands. This speculation is supported by the fact that planted stands on Alfisols had lower $\mathrm{N}$ mineralization (and ANPP) than natural stands on Alfisols. These differences were not related to differences in soil texture (mean percentage silt plus clay $\approx 70 \%$ in both groups), but perhaps to stand age and time for replenishment of soil organic matter and $\mathrm{N}$ cycling rates following farm abandonment (Pastor and Post 1986, Aber et al. 1991). All stands planted on Alfisols were between 30 and 40 $\mathrm{yr}$ old at the time of measurement, whereas all the natural stands on Alfisols were older in terms of tree age, but more importantly, in time since major soil disturbance (probably hundreds of years).

However, from the data for the 50 stands in this study, it appears that soil and climate effects are sufficiently strong that they either limit or mask the differential litter quality feedbacks from different forest types. For example, Meentemeyer (1978) showed that percentage leaf litter lignin exerted a greater control on litter decomposition in warm, moist areas vs. cold, dry climates. Thus, although we know that feedbacks can occur (Wedin and Tilman 1990, Gower and Son 1992, Van Vuuren et al. 1992) it may be that across this regional scale (and associated levels of heterogeneity), soils and climate largely determine both vegetation and $\mathrm{N}$ cycling regimes, and feedbacks are less important. If this is the case (and only a larger data set structured to directly address such issues can fully answer this question), then models of ecosystem, landscape, and regional scale $\mathrm{N}$ cycling and productivity may need to be altered to reflect these patterns.

The significantly greater mean ANPP and N mineralization rates of natural hardwood than conifer stands, but comparable rates when soil type and stand origin are controlled, may have important implications. These results suggest that observed average differences among natural forest types in ANPP and N mineralization resulted from differences in their distribution on varying soils, and not their performance on comparable soils. The distribution of forest types (on natural stands) across soil types in this study was not obtained in a way that it can be formally compared with natural distribution patterns, but similarities between the two exist. In the Great Lakes states, conifers are predominantly found on less fertile soils, often of coarser texture (pines especially), whereas hardwoods occupy a broad range of soils, including those of finer texture and higher fertility (Curtis 1959, Kotar et al. 1988). Thus, it may be that at a regional scale, hardwood forests have higher average ANPP and N mineralization rates than evergreen conifers, due to soil control on vegetation distribution patterns, $\mathrm{N}$ cycling, and ANPP. Feedbacks that favor higher $\mathrm{N}$ cycling and ANPP on hardwood than evergreen conifer sites would exacerbate these differences. 


\section{Relationship between ANPP and $N$ mineralization rate}

Analyses of all 50 stands also provide a framework to reconcile most of the previous discrepancies (from individual studies) about the form and/or existence of the ANPP-N mineralization relationship in cold temperate forests. Across the broad location/soil/forest type/stand origin mixture in this data set, ANPP was linearly related to $\mathrm{N}$ availability, both for all data pooled as well as for data subsets grouped by forest type, soil type, and land history type. These results suggest that the ANPP-N mineralization relationship is likely a fundamental feature of temperate forest ecosystems, although the form of the relationship may vary with biotic, abiotic, and disturbance factors. Such a linear relationship likely results from the impact of $\mathrm{N}$ availability on productivity, and potentially from the long-term feedback effects of vegetation on $\mathrm{N}$ availability. The regional relationship shows no indication of $\mathrm{N}$ saturation, is comparable in strength to those found across some specific landform/soil/vegetation sequences (which reinforce the relationship)(e.g., Pastor et al. 1984, Zak et al. 1989), and is clearly a general trend that encompasses single-location studies where there were no ANPP-N mineralization relationships for smaller numbers of closed-canopy stands (e.g., Gower and Son 1992, Gower et al. 1993, Grigal and Homann 1994).

All stands fit within a broad general relationship between ANPP and N mineralization, regardless of forest type. There was no tendency for conifers to differ from hardwood stands in ANPP when grown at comparable levels of $\mathrm{N}$ availability (i.e., mineralization rates) or for stands of comparable total litterfall $\mathrm{N}$ cycling. The latter pattern has been noted previously (Cole and Rapp 1981), but to our knowledge no comparison such as the former has been made previously for as large a number of stands across a diversity of soil types. How do evergreen conifers achieve similar ANPP at a given $\mathrm{N}$ mineralization rate as hardwoods? Previous work has shown that evergreen conifers have much lower canopy foliage efficiency (Reich et al. 1992), lower leaf percentage N (Reich et al. 1992), and lower photosynthetic capacity per unit leaf N (Reich et al. 1992, 1995, Gower et al. 1993). However, the accumulation of foliage mass and area that results from long leaf life-span increases total canopy photosynthesis (Gower and Richards 1990, Reich et al. 1992, Gower et al. 1993), effectively offsetting the lower potential productivity per unit foliage (low foliage efficiency). Hence, ANPP per unit $\mathrm{N}$ available or $\mathrm{N}$ cycled is similar for conifer and hardwood species. The cost of being evergreen (of extended leaf life-span and low tissue $\mathrm{N}$ concentrations) could involve a negative feedback on $\mathrm{N}$ mineralization (Pastor et al. 1984, Gower and Son 1992), although data in this paper provide no such evidence for stands of similar origin on similar soils.
It is well known that across global gradients, ANPP is well correlated with litterfall $\mathrm{N}$ (Cole and Rapp 1981). However, for the 50 sites in this analysis, ANPP was much more closely related to annual $\mathrm{N}$ mineralization than to litterfall $\mathrm{N}$ cycled, despite the obvious partial autocorrelation of ANPP with litterfall $\mathrm{N}$ as measured in these studies (litter $\mathrm{N}$ is determined from total litter mass, which is a component of ANPP). Moreover, wood production, which is measured independently of both mineralized and litterfall N, was also highly correlated with mineralized $\mathrm{N}$, but very weakly related to litterfall N. Thus, for these 50 stands, the relationship between productivity and soil $\mathrm{N}$ supply was more robust than those between productivity and aboveground litterfall $\mathrm{N}$, or between aboveground litterfall $\mathrm{N}$ and mineralized $\mathrm{N}$. The fact that ANPP was more highly correlated to soil $\mathrm{N}$ mineralization than to litterfall $\mathrm{N}$ content suggests that variability in microbial processes is important, and correlated to ANPP (Zak et al. 1989, 1994). Litterfall N content does not account for variation in carbon constituents that may influence soil N mineralization (Aber and Melillo 1982). Gower and Son (1992) found that the ratio of litterfall lignin: $\mathrm{N}$ content explained a significantly greater fraction of the variation in annual $\mathrm{N}$ mineralized among plantations of five tree species than did litterfall $\mathrm{N}$ content. Better knowledge of belowground productivity and root litter $\mathrm{N}$ dynamics would help to enable the balancing of these biomass and $\mathrm{N}$ budgets (Aber et al. 1985, Nadelhoffer et al. 1985, Wedin and Tilman 1990). Data from long-term stand averages would be necessary, since the comparisons in this study implicitly assume year-to-year equilibrium and no disjunction in time of ANPP, $\mathrm{N}$ in litterfall, and $\mathrm{N}$ mineralization.

\section{CONCLUSIONS}

Soil properties had significant impacts on $\mathrm{N}$ mineralization and ANPP, and on their relationship, supporting the paradigm that proximate control of productivity of temperate forest ecosystems is linked to their $\mathrm{N}$ status. A remaining, nagging question, however, is whether other site characteristics lead to both greater productivity and higher $\mathrm{N}$ status of those systems, whether $\mathrm{N}$ status is an effect and not a cause, or both cause and effect. It is our opinion that the latter is most likely: these are systems, which implies feedbacks and cycles, rather than cause and effect. These data, spanning a range of climate, soils, and vegetation within the same biome, indicate intrinsically higher $\mathrm{N}$ status and greater productivity on Alfisol soils compared to Entisols, and greater productivity even at a given $\mathrm{N}$ status. Alfisols tend to have higher base cation status and better water-retention characteristics than do Entisols, and low soil $\mathrm{pH}$ and soil water availability can inhibit N mineralization (Jones and Richards 1977). However, why is ANPP at a given $\mathrm{N}$ mineralization greater on Alfisols than Entisols? It is possible that limitations due to water shortage and/or other base nu- 
trients are more common on Entisols than Alfisols, physiologically reducing tree productivity at a given $\mathrm{N}$ availability. Albeit indirectly, these data therefore indicate that although $\mathrm{N}$ status may be an important proximate control of productivity, inherent site differences related to the geological substrate (i.e., soil parent material and stage of mineral weathering) exert strong influence on the $\mathrm{N}$ resource and its use.

\section{ACKNOWLEDGMENTS}

We thank the numerous scientists and technicians who were involved in the original research on these study sites, and especially E. Sucoff, D. Kim and A. Ek for making available unpublished data from the Cloquet Forestry Center. Critical reviews by S. Friedman, J. L. Machado, and D. Peterson were also helpful. We acknowledge support from the National Science Foundation Long-Term Ecological Research Program (DEB-9411972), the interagency Terrestrial Ecology and Global Change Program (DEB-9524078), and the University of Minnesota during this project.

\section{Literature Cited}

Aber, J. D., and J. M. Melillo. 1982. Nitrogen immobilization in decaying hardwood leaf litter as a function of initial nitrogen and lignin content. Canadian Journal of Botany 60:2263-2269.

Aber, J. D., J. M. Melillo, N. J. Nadelhoffer, C. A. McClaugherty, and J. Pastor. 1985. Fine root turnover in forest ecosystems in relation to quantity and form of nitrogen availability: a comparison of two methods. Oecologia 66: 317-321.

Aber, J. D., J. M. Melillo, N. J. Nadelhoffer, J. Pastor, and R. D. Boone. 1991. Factors controlling nitrogen cycling and nitrogen saturation in northern temperate forest ecosystems. Ecological Applications 1:303-315.

Binkley, D., and S. C. Hart. 1989. The components of nitrogen availability assessments in forest soils. Advances in Soil Science 10:57-112.

Buol, S. W., F. D. Hole, and R. J. McCracken. 1980. Soils genesis and classification. Second edition. Iowa State University Press, Ames, Iowa, USA.

Cole, D. W., and M. Rapp. 1981. Elemental cycling in forest ecosystems. Pages 341-409 in Dynamic properties of forest ecosystems. Cambridge University Press, Cambridge, England.

Curtis, J. T. 1959. The vegetation of Wisconsin. University of Wisconsin Press, Madison, Wisconsin, USA.

Flanagan, P. W., and K. Van Cleve. 1983. Nutrient cycling in relation to decomposition and organic matter quality in taiga ecosystems. Canadian Journal of Forest Research 13: 795-817.

Fownes, J. H. 1985. Water use and primary production in Wisconsin hardwood forests. Dissertation. University of Wisconsin-Madison, Wisconsin, USA.

Gosz, J. R. 1981. Nitrogen cycling in coniferous ecosystems. In F. E. Clark and T. Rosswall, editors. Terrestrial nitrogen cycles. Ecological Bulletins-NFR 33:405-426.

Gower, S. T., P. B. Reich, and Y. Son. 1993. Canopy dynamics and aboveground production of five tree species with different leaf longevities. Tree Physiology 12:327345.

Gower, S. T., and J. H. Richards. 1990. Larches: deciduous conifers in an evergreen world. BioScience 40:818-826.

Gower, S. T., and Y. Son. 1992. Differences in soil and leaf litterfall nitrogen dynamics for five forest plantations. Soil Science Society of America Journal 56:1959-1966.

Grigal, D. F., and P. Homann. 1994. Nitrogen mineralization, groundwater dynamics, and forest growth on a Minnesota outwash landscape. Biogeochemistry 27:171-185.
Haynes, B. E., and S. T. Gower. 1995. Belowground carbon allocation in unfertilized and fertilized red pine plantations in northern Wisconsin. Tree Physiology 15:317-325.

Jones, J. M., and B. N. Richards. 1977. Effect of reforestation on turnover of $15 \mathrm{~N}$-labelled nitrate and ammonia in relation to changes in soil microflora. Soil Biology and Biochemistry 9:383-392.

Kotar, J., J. A. Kovach, and C. T. Locey. 1988. Field guide to forest habitat types of northern Wisconsin. Department of Forestry, University of Wisconsin-Madison and the Wisconsin Department of Natural Resources, Madison, Wisconsin, USA.

Lennon, J. M., J. D. Aber, and J. M. Melillo. 1985. Primary production and nitrogen allocation of field grown sugar maples in relation to nitrogen availability. Biogeochemistry 1:135-154.

McMurtie, R. E., H. L. Gholz, S. Linder, and S. T. Gower. 1994. Climatic factors controlling productivity of pine stands: a model based analysis. Ecological Bulletins-NFR 43: $173-188$.

Meentemeyer, V. M. 1978. Macroclimate and lignin control of litter decomposition rates. Ecology 59:465-472.

Mladenoff, D. J. 1987. Dynamics of nitrogen mineralization and nitrification in hemlock and hardwood treefall gaps. Ecology 68:1171-1180.

Nadelhoffer, N. J., J. D. Aber, and J. M. Melillo. 1983. Leaflitter production and soil organic matter dynamics along a nitrogen-availability gradient in southern Wisconsin. Canadian Journal of Forest Research 13:12-21.

Nadelhoffer, N. J., J. D. Aber, and J. M. Melillo. 1985. Fine roots, net primary production, and soil nitrogen availability: a new hypothesis. Ecology 66:1377-1390.

Pastor, J., J. D. Aber, C. A. McClaugherty, and J. M. Melillo. 1984. Aboveground production and $\mathrm{N}$ and $\mathrm{P}$ cycling along a nitrogen mineralization gradient on Blackhawk Island, Wisconsin. Ecology 65:256-268.

Pastor, J., B. Dewey, R. J. Naiman, P. F. McInnes, and Y. Cohen. 1993. Moose browsing and soil fertility in the boreal forests of Isle Royale National Park. Ecology 74: 467-480.

Pastor, J., and W. M. Post. 1986. Influence of climate, soil moisture, and succession on forest carbon and nitrogen cycles. Biogeochemistry 2:3-27.

Reich, P. B., M. B. Walters, and D. S. Ellsworth. 1992. Leaf life-span in relation to leaf, plant and stand processes in diverse ecosystems. Ecological Monographs 62:365-392.

Reich, P. B., B. D. Kloeppel, D. S. Ellsworth, and M. B. Walters. 1995. Different nitrogen-photosynthesis relationships in deciduous hardwood and evergreen coniferous tree species. Oecologia 104:24-30.

SAS. 1994. JMP statistics and graphics guide: version 3 . SAS Institute, Cary, North Carolina, USA.

USDA. 1975. Soil Conservation Service. Soil Survey Staff. Soil taxonomy: a basic system of soil classification for making and interpreting soil surveys. U.S. Department of Agriculture Handbook 436. U.S. Government Printing Office, Washington, D.C., USA.

Van Cleve, K., L. K. Oliver, P. Schlentner, L. A. Viereck, and C. T. Dyrness. 1983. Productivity and nutrient cycling in taiga forest ecosystems. Canadian Journal of Forest Research 13:747-766.

Van Cleve, K., J. Yarie, R. Erickson, and C. T. Dyrness. 1993. Nitrogen mineralization and nitrification in successional ecosystems on the Tanana River floodplain, interior Alaska. Canadian Journal of Forest Research 23:970-978.

Van Vuuren, M. M. I., R. Aerts, F. Berendse, and W. de Visser. 1992. Nitrogen mineralization in heathland ecosystems dominated by different plant species. Biogeochemistry 16: 151-166.

Walters, M. B., and P. B. Reich. 1997. Growth of Acer sac- 
charum seedlings in deeply shaded forest understories of northern Wisconsin: effects of nitrogen and water availability. Canadian Journal of Forest Research, in press.

Wedin, D. A., and D. Tilman. 1990. Species effects on nitrogen cycling: a test with perennial grasses. Oecologia 84: 433-441.

Zak, D. R., and D. F. Grigal. 1991. Nitrogen cycling in upland and wetland ecosystems of east-central Minnesota. Oecologia 88:189-196.

Zak, D. R., G. E. Host, and K. S. Pregitzer. 1989. Regional variability in nitrogen mineralization, nitrification and overstory biomass in northern Lower Michigan. Canadian Journal of Forest Research 19:1521-1526.
Zak, D. R., and K. S. Pregitzer. 1990. Spatial and temporal variability of nitrogen cycling in northern Lower Michigan. Forest Science 36:367-380.

Zak, D. R., K. S. Pregitzer, and G. E. Host. 1986. Landscape variation in nitrogen mineralization and nitrification. Canadian Journal of Forest Research 16:1258-1263.

Zak, D. R., D. Tilman, R. R. Parmenter, C. W. Rice, F. M. Fisher, J. Vose, D. Milchunas, and C. W. Martin. 1994. Plant production and soil microorganisms in late-successional ecosystems: a continental scale study. Ecology 75: 2333-2347. 